\title{
SURVIVAL AND MUTANT PRODUCTION INDUCED BY MUTAGENIC AGENTS IN Metarhizium anisopliae
}

\author{
V. KAVA - CORDEIRO; E.A. LUNA - ALVES - LIMA3; J.L. AZEVEDO4 \\ 2 Depto. Genetica/UFPR, C.P. 19071 CEP: 81531-990 - Curitba, PR \\ 'Depto.Micologia/UFPR, CEP: 50670-901, Recle,PE \\ ¿Depto. Genctica/ESALOJUSP, C.P. 83, CEP: 13418-900 - Pinacicaba, SP
}

\begin{abstract}
A wild strain of Metarhizlum anlsopliae, an entomopathogenic fungus, was submitted to three mutagenic agents: gamma radiation, ultraviolet light and nitrous acid. Survival curves were obtained and mutants were selected using different mutagenic doses which gave 1 to $5 \%$ survival. Morphological and atuxotrophic mutants were isolated. Morphological mutants were grouped in a class with yellow conidia and other with pale vinaceous conidia as opposed to the green wild type conidia. Auxotrophic mutants had requirements for vitamin and aminoacid biosynthesis. More than 58\% of the total auxotrophic mutants required proline/arginine. Gamma radiation showed to be the most efficient mutagenic agent giving $0.2 \%$ of awxotrophic mutants followed by ultraviolet light $(0.12 \%)$ and nitrous acid $(0.06 \%)$. The conidial colour and anxotrophic mutants isolated until now from $M$. anisopliae were reviewed.
\end{abstract} Key Words: Metarhizium anisopliae, auxotrophic mutants, colour mutants, mutagenic agents, gamma radiation, ultraviolet light, nitrous acid

\section{SOBREVIVENCIA E OBTENÇÃO DE MUTANTES INDUZIDOS POR AGENTES MUTAGENICOS EM Metarhizium anisopliae.}

RESUMO: Uma linhagem selvagem do fungo entomopatogênico Metarhizium anisopllae foi submetida à ação de três agentes mutagénicos: radiaģ̃o gama, luz ultravioleta e ácido mitroso. Curvas de sobrevivência foram obtidas para cada mutagenico utilizado e mutantes foram selecionados a partir de doses dos mutagénicos que proporcionassem de 1 a 5\% de sobrevivencia. Mutantes morfologicos para a coloração de confdios e mutantes auxotroficos foram isolados. Mutantes para coloraçio de conídios foram agrupados em duas classes, uma com conídios amarelos e outra com conidios vinho palido. Os mutantes auxotroficos obtidos foram deficientes para aminoscidos e vitaminas e mais de 58\% deles eram auxotroficos para prolina/arginina. Radiaçăo gama foi o mutagênico mais eficiente com uma porcentagem de obtençăo de mutantes auxotroficos de aproximadamente $0,2 \%$, seguido pela luz ultravioleta (0.12\%) e pelo scido nitroso (0.06\%).Os mutantes morfologicos e anxotroficos obtidos até o momento em Metarhishum anisopliae foram revistos.

Descritores: Metarhizium anisopliae, agentes mutagenicos, mutantes auxotroficos, mutantes para coloraçăo, madiaç̆̊ gama, luz ultravioleta, 6́cido nitroso

\section{INTRODUCTION}

Metarhizium anisopliae is a filamentous fungus which is used in Brazil mainly for biological control of pasture and sugarcane pests. The fungus also shows good potential for the control of many other species of insects (ALVES, 1986). Strains of distinct origins have been characterized on the basis of several parameters such as electrophoretic tests (DE CONTI et al, 1980), size of conidia (AZEVEDO \& MESSIAS, 1981), enzyme production (ROSATO et al.,1981), virulence (AL-AIDROOS \& ROBERTS, 1978), PFGE (KAVA-CORDEIRO et al.,1993) and
RAPD (FUNGARO et al.,1994). The parasexual cycle of this species has already been described (MESSIAS,1979) (MESSIAS \& AZEVEDO,1980) (AL AIDROOS,1980). The parameiosis, a derivation of the parasexual cycle was also detected in $M$. anisopliae (SILVEIRA \& AZEVEDO, 1987) (BAGAGLI et al, 1991). Mutagenic agents have been used to obtain mutants in this fungus for genetic studies as well as a method for genetic improvement for applied purposes (OKINO et al.,1978) (AZEVEDO et al.,1987). Several mutagenic agents can be used to induce mutants in fungi. The objective of the present study was to compare the efficacy

1 Trabalho financiado pelo CNPQ e CAPES. 
of three mutagenic agents: gamma radiation, ultraviolet light and nitrous acid in a wild type strain of Metarhizium anisopliae. These mutagenic were chosen because gamma radiation is a type of ionizing irradiation that produces mainly random mutations in DNA. Ultraviolet light is a non-ionizing irradiation that produces mainly DNA base-pair changes and, nitrous acid is a chemical mutagen which produces desamination of DNA components (GARDNER \& SNUSTAD, 1986). Besides, ultraviolet light and nitrous acid are easily found in research laboratories and a gamma radiation source if available, permits rapid and simple utilization.

\section{MATERIAL AND METHODS}

1) Strain: The AL Metarhizium anisopliae strain was used in the present study. It was isolated from Deois flavopicta (Homoptera, Cercopidae) collected in the State of Alagoas, Brazil.

2) Culture Media and General Procedures: Minimal Medium (MM) and Complete Medium (CM) were those of PONTECORVO et al. (1953) and modified by AZEVEDO \& COSTA (1973). To the solid media $1.5 \%$ agar was added. Conidial suspensions were prepared from 8 days inoculated colonies on CM. The conidia were collected from the colonies and suspended in tween $80(0.1 \% \mathrm{v} / \mathrm{v})$. After shaking they were counted using a Neubauer chamber. They were properly diluted in $0.85 \%(w / v)$ saline $(\mathrm{NaCl})$ before treatment with the mutagenic agents. Incubation was at $28^{\circ} \mathrm{C}$ in all experiments.

3) Survival Curves and Isolation of Mutants: A survival curve was made with a range of doses of all mutagenic agents to determine the one which would allow 1 to $5 \%$ survival. Doses between these survivals provide a good recovery of mutants as described by BURNETT (1975). A dose-response curve for survival and production of mutants from gamma radiation (Source of $\mathrm{Co}^{60}$ from "Centro de Energia Nuclear na Agricultura", CENA, Piracicaba,S.P.), ultraviolet light and nitrous acid treatments followed the methodology described respectively by OKINO et al. (1978), TINLINE \& NOVIELLO (1971) and AZEVEDO (1970). Morphological mutants could be distinguished visually and were readily isolated and stored on CM agar slopes. To isolate auxotrophic mutants, conidia after treatment, were plated on CM agar. Colonies growing on this medium were individually transferred to plates of $M M$ using a $5 \times 5+1$ arrangement (AZEVEDO et al., 1976). Colonies which failed to grow on $M M$ were assumed as being possible auxotrophic mutants. The site where they were inoculated into MM solid medium was cut out and transferred to tubes containing $C M$ agar slopes. After 8 days incubation at $28^{\circ} \mathrm{C}$ each isolated was tested for nutritional requirements as described by AZEVEDO \& COSTA (1973).

Table 1. Percentage of survival from conidia of Metarhizium anisopliae exposed to gamma radiation, ultraviolet light and nitrous acid.

\begin{tabular}{|c|c|c|c|c|c|}
\hline \multicolumn{2}{|c|}{ GAMMA RADIATION } & \multicolumn{2}{|c|}{ ULTRAVIOLET LIGHT } & \multicolumn{2}{|c|}{ NITROUS ACID } \\
\hline DOSE (Grays) & $\%$ survival & DOSE $\left(J / m^{2}\right)$ & \% survival & TIME (min) & $\%$ survival \\
\hline $\mathbf{0}$ & 100.00 & $\mathbf{0}$ & 100.00 & 0 & 100.00 \\
\hline 100 & 51.20 & 75 & 15.63 & 4 & 59.02 \\
\hline 200 & 9.40 & 150 & 1.88 & 8 & 29.80 \\
\hline 400 & 2.40 & 225 & 1.13 & 12 & 5.00 \\
\hline 600 & 0.26 & 300 & 0.01 & 16 & 1.54 \\
\hline 800 & 0.09 & 600 & 0.00 & 20 & 0.43 \\
\hline
\end{tabular}




\section{RESULTS AND DISCUSSION}

1) Survival Curves: TABLE 1 shows the results of gamma radiation, ultraviolet light and nitrous acid for conidial survival of the AL strain of Metarhizium anisopliae. The dose utilized for mutant production

TABLE 2. Percentages of auxotrophic mutants found after treatment of Metarhizium anisopliae with gamma radiation, ultraviolet light and nitrous acid.

\begin{tabular}{lc}
\hline \hline AUXOTROPHIES & PERCENTAGES \\
\hline Arginine/Proline & 58.33 \\
Nicotinic acid & 16.66 \\
p-Aminobenzoic acid & 8.33 \\
Methionine & 8.33 \\
Valine & 8.33 \\
\hline
\end{tabular}

was then 400 Grays for gamma radiation, $150 \mathrm{~J} / \mathrm{m}^{2}$ for ultraviolet light.For nitrous acid (final concentration $0.017 \mathrm{M}$ ), time of treatment was 12 minutes.

2)Mutant Production: Morphological and auxotrophic mutants were investigated. Morphological mutants with distinct colony phenotypes were not considered. Only conidial colours mutants were studied. These showed distinct colony colours which were grouped in two main classes, the first one with yellow conidia, presenting different nuances of this colour and, the second, with homogeneous pale vinaceous conidia. All mutagenic agents used originated both classes of colour mutants. No attempt to quantify these mutants was carried out.

Auxotrophic mutants showed requirements for vitamins and aminoacids biosynthesis. TABLE 2 shows the percentages of the auxotrophies found. $58.33 \%$ of the whole auxotrophic mutants were deficient to arginine biosynthesis. These mutants also were able to grow when proline, ornithine or citrulline was added to $M M$, showing that this

TABLE 3. A survey of conidial colour mutants isolated from Metarhizium anisoliae.

\begin{tabular}{lccc}
\hline \hline COLOUR & SIMBOLOGY & STRAINS & REFERENCES**** \\
\hline yellow & $\underline{\text { ylo }}$ & A4,AL,E6,M,M5, & $1,3,4,5,6,8,9$, \\
& & Ma140,Mj,MT,5,RJ & 10,12 \\
pale vinaceous & $\underline{\text { pvi }}$ & A4,AL,E6,E9,M,MT,RJ & $3,4,5,6,8,10,12$ \\
white & $\underline{\text { whi }}$ & E6,E9,Ma140,RJ & $6,8,9$ \\
brown* & $\underline{\text { brn }}$ & 5 & 1 \\
tan* & $\underline{\text { tan }}$ & 5 & 1 \\
lemon & $\underline{\text { lem }}$ & $5, \mathrm{E} 9$ & 2,8 \\
red** & & 5 & 2 \\
rust(mustard)** & & 5 & 7 \\
orange** & & 5 & 7 \\
buff** & & 1 & 11 \\
\hline \hline
\end{tabular}

* could be the pvi according to RAYNER (1970) Colour Chart.

** derived from mitotic recombination.

*** type of yellow.

**** 1 AL-AIDROOS (1980) ; 2 BERGERON (1982) ; 3 BAGALHI (1987); 4 COSTA (1989) ; 5 FRIGO (1983) ; 6 LUNA-ALVES-LIMA (1985); 7 MAGOON; MESSING-AL-AIDROOS (1986); 8 MESSIAS; AZEVEDO (1980) ; 9 RIBA et al.(1985) ; 10 SILVEIRA; AZEVEDO (1984) ;11 TINLINE; NOVIELO (1971); 12 This paper. 
TABLE 4. A survey of auxotrophic mutants isolated from Metarhizium anisopliae.

\begin{tabular}{|c|c|c|c|c|}
\hline AUXOTROPHY & SIMBOLOGY & No. MUTANTS & STRAIN & REFERENCES**** \\
\hline \multicolumn{5}{|l|}{ AMINOACIDS } \\
\hline arginine & $\underline{\arg }$ & 11 & A4,E9,M,M5,Ma140 & $1,5,8,10$ \\
\hline cysteine & cys & 3 & E6,RJ & 5,11 \\
\hline histidine & his & 1 & 8P-1 & 12 \\
\hline isoleucine/valine & iv & 1 & 8P-1 & 12 \\
\hline leucine & leu & 7 & $\mathrm{E} 6,5$ & 1,7 \\
\hline lysine & lys & 34 & $\begin{array}{l}\text { A4,E6,M, M5,MT,RJ,5, } \\
\text { 8P-1 }\end{array}$ & $\begin{array}{l}1,2,3,4,5,7,9 \\
11,12\end{array}$ \\
\hline methionine & met & 35 & $\begin{array}{l}\text { A4,AL,E6,E9,M,MT,RJ,5, } \\
\text { 8P-1 }\end{array}$ & $\begin{array}{l}1,3,4,5,7,8,9 \\
11,12,13\end{array}$ \\
\hline proline/arginine & pro & 8 & AL,E9 & 1,13 \\
\hline valine & val & 2 & AL, RJ & 11,13 \\
\hline not determined* & & 12 & E9,RJ & 1 \\
\hline \multicolumn{5}{|l|}{ VITAMINS } \\
\hline biotin & $\underline{\text { bio }}$ & 6 & A4,E6,RJ,8P-1 & $1,4,11,12$ \\
\hline nicotinic acid & $\underline{\text { nic }}$ & 8 & AL,E6,E9,M,MT & $1,4,9,11,13$ \\
\hline p-aminobenzoic acid & pab & 2 & $A L, E 9$ & 8,12 \\
\hline pyridoxin & pyr & 6 & E6,E9,RJ & $1,5,8,11$ \\
\hline riboflavin & $\underline{\text { rib }}$ & 1 & E9 & 1 \\
\hline thiamine & $\underline{\text { thi }}$ & 5 & E9,Ma140,MT,5 & $6,8,9,10$ \\
\hline not determined** & & 6 & E9 & 1 \\
\hline \multicolumn{5}{|l|}{ PURINES } \\
\hline adenine & $\underline{\text { ade }}$ & 20 & $\mathrm{A4}, \mathrm{AL}, \mathrm{E} 6, \mathrm{M}, \mathrm{RJ}, 5$ & $1,2,3,4,5,11$ \\
\hline guanine & gua & 1 & E6 & 1 \\
\hline
\end{tabular}

* growth on hydrolysed casein.

** growth on vitamins solution.

*** 1 BAGALHI (1987), 2 BERGERON (1982), 3 BERGERON; MESSING-AL- AIDROOS (1982), 4 FRIGO (1983), 5 LUNA-ALVES-LIMA (1985), 6 MAGOON; MESSING-AL-AIDROOS (1984), 7 MAGOON; MESSING-AL-AIDROOS (1986), 8 MESSIAS; AZEVEDO (1980), 9 PAMPHILE (1992), 10 RIBA et al. (1985), 11 SILVEIRA; AZEVEDO (1984), 12 TINLINE; NOVIELLO (1971), 13 This paper.

Not always the reference quotes the paper which report the mutant for the first time. 
fungus has the steps of arginine biosynthesis chain similar to those found in other filamentous fungi and bacteria (HAYES, 1964). The results also shown that mutation occurs at the one of the first steps of this chain.

Gamma radiation gave $0.2 \%$, ultraviolet light $0.12 \%$ and nitrous acid gave $0.06 \%$ auxotrophic mutants. These results are comparable to those found by other authors. MESSIAS (1979) using ultraviolet light found $0.1 \%$ auxotrophic mutants in $M$. anisopliae in two strains (E6 and E9) used. LUNAALVES-LIMA (1985) using also ultraviolet light found $0.16 \%$ auxotrophic mutants in the same strain used in the present work. Similar results $(0.16 \%$ to $0.3 \%$ ) were found by BAGALHI (1987) using strains E6, E9 and RJ. A higher percentage of auxotrophic mutants was found when, instead of the total isolation technique, the enrichment by filtration technique was used. SILVEIRA \& AZEVEDO (1984) showed an increase of 61 times and BAGALHI (1987) an increase of 10.7 times in the auxotrophic mutant frequency using this technique.

It was not surprising that gamma radiation was the best mutagenic agent for $M$. anisopliae. The same is found almost invariably for other fungi (PACCOLA-MEIRELLES \& AZEVEDO, 1991) (GOLDMAN, 1988) (PIMENTEL, 1991). However, the use of this mutagenic is in general avoided due to the high frequencies of chromosomal aberrations which are induced, making difficult any further genetic analysis. Nitrous acid, on the other hand, has some advantages as to be easily controlled and safe to hand (LIMEIRA JR. et al., 1991). However it has a low efficiency to produce mutants as compared to other agents as shown in this paper, at least for the strain and time of exposure used. In Aspergillus nidulans, SIDDIQI (1962) found four times more auxotrophic mutants induced by nitrous acid than in the present work.

Now, after about 15 years of genetic research in $\boldsymbol{M}$. anisopliae a significant number of morphological and auxotrophic mutants were already isolated from different laboratories and strains. This produce sufficient data to make some comparisons and considerations. From 8 or 9 types of colour mutants described in the available literature of $M$. anisopliae, two are the most frequently found. These are the yellow (ylo) and the pale vinaceous (pvi) colour mutants. Colourless or white (whi) conidia were found in four strains studied and the lemon mutant in two strains. The mutant described as tan or brown (AL-AIDROOS, 1980) are perhaps the pale vinaceous mutants if the Mycological Colour Chart (RAYNER, 1970) would been used. Other mutants found by MAGOON \& MESSING-AL-AIDROOS (1986) as the orange, red, mustard and rust were produced by mitotic recombination and probably are the result of interactions among other colour mutants or even the result of chromosomal aberrations as aneuploidy for instance (TABLE 3). Considering now the auxotrophic mutants, they were already isolated from different strains, for 6 vitamins, 9 aminoacids and 2 purines, besides some mutants which respond to a pool of vitamins or to hydrolysed casein. TABLE 4 shows that 114 aminoacid deficient mutants, 34 vitamin and 21 purine deficient mutants were isolated till now in $M$. anisopliae. This relation is to be expected since there are more aminoacids (20) than vitamins (6) and purines (2) used in CM. Also the enrichment by filtration technique seems to favour the aminoacid mutants isolation (SILVEIRA \& AZEVEDO, 1984). The absence of pyrimidines auxotrophic mutants is explained by the inability of pyrimidines to penetrate into the cell as occurs in other fungi making these mutants lethals. The higher number of some auxotrophic mutants found in certain experiments as 16 methionine mutants (BAGALHI, 1987) or 13 lysine mutants (SILVEIRA \& AZEVEDO, 1984) can be explained by clone isolation, a bias to select some types of mutants or a combination of mutant isolation technique, strain and mutagenic used. In any way, $M$. anisopliae has a reasonable number of mutants already isolated from distinct strains. Unfortunately not all are available at the moment since several were lost during precarious preservation techniques. As far it is known, the procedure described by CASTELLANI (1967) as show by BAGALHI \& AZEVEDO (1986) is the most reliable method and should be used to preserve strains of $M$. anisopliae.

\section{CONCLUSIONS}

1 From the 3 mutagenic agents used, gamma radiation was the more effective to induce mutants in $\boldsymbol{M}$. anisopliae.

2 All mutagenic agents produced two types of colour mutants and auxotrophic mutants.

3 Proline/arginine was the most frequent auxotrophic mutant found.

4 A review of mutants already isolated in $M$. anisopliae shows that the number of mutants is con- 
siderable and permits further genetic studies in the species.

\section{REFERENCES}

AL-AIDROOS, K. Demonstration of parasexual cycle in the entomopathogenic fungus Metarhizitum anisopliae. Canadian Journal of Genetics and Cytology, v.22, p.309-314, 1980.

AL-AIDROOS, K.; ROBERTS, D.W. Mutants of Metarhizium anisopliae with increase virulence toward mosquito larvae. Canadian Journal of Genetics and Cytology, v.20, p.211-219, 1978.

ALVES, S.B. Controle microbiano de insetos. São Paulo: Manole, 1986. 407p.

AZEVEDO, J.L. Recessive lethal induced by nitrous acid in Aspergillus nidulans. Mutation Research, v.10, p.111-117,1970.

AZEVEDO,J.L. ; COSTA. S.O.P. Exencícios praticos de genética. São Paulo:EDUSP, 1973. 288p.

AZEVEDO, J.L. ; MESSIAS C.L. Tamanho de conidios em diferentes isolados de Metarhizium anisopliae. Boletim do Grupo Pesquisadores de Controle Biologico, v.2, p.5-8, 1981.

AZEVEDO, J.L. ; MESSIAS, C.L. ; SILVEIRA,W.D. Genetics and breeding of the entomopathogenic fungus Metarhizium anisopliae: parasexuality and protoplast fusion. In: CROCOMO, O.J., TAVARES, F.C.A., Biotechnology of plants and microorganisms Columbus: Ohio State University Press, 1987. chapter 21, p.305-318.

AZEVEDO, J.L. ; OLIVEIRA, A.; CAMPOS, A.J.R. Replicador multifio para transferência de esporos de fungos filamentosos.Summa Phytopathologica, v.2, p.237-241, 1976 .

BAGALHI, E. Parameiose em Metarhizium anisopllae (Metsch.) Sorokin. Piracicaba, 1987. 124p. Dissertação(mestrado)-Escola Superior de Agricultura "Luiz de Queiroz", Universidade de São Paulo.

BAGALHI, E. ; AZEVEDO, J.L. Preservação de linhagens selvagens e mutantes de Metarhizium anisopliae. In: REUNIÃO ANUAL DE GENETICA DE MICRORGANISMOS, 13, Ribeirão Preto, 1986. Resumos. Ribeirão Preto: SBG, 1986. p.59.
BAGAGLI, E. ; VALADARES, M.C.C. ; AZEVEDO, J.L. Parameiosis in the entomophatogenic fungus Metarhizium anisopliae (Metsch.) Sorokin. Revista Brasileira de Genćtica, v.14, p.261-271, 1991.

BERGERON, D. Cycle parasexual chez Metarhizium anisopliae. Montreal, 1982. Thesis (M.Sc.)Departement des Sciences Biologiques, Université du Québec.

BERGERON, D. ; MESSING-AL-AIDROOS, K. Haploidization analysis of heterozygous diploids in the entomogenous fungus Metarhizium anisopliae. Canadien Journal of Genetics and Cytology, v.24, p.643$651,1982$.

BURNETT, J.H. Mycogenetics. London: John Wiley \& Sons, 1975.375p.

CASTELLANI, A. Maintenance and cultivation of common pathogenic fungal in sterile distilled water for researches. Journal of Tropical Medicine and Hygiene, v.70, p.181-184, 1967.

COSTA, C. Diversidade biológica em Metarhizium anisopliae (Metsch.)Sorokin. Piracicaba, 1989. 182p. Tese (PhD)- Escola Superior de Agricultura "Luiz de Queiroz”, Universidade de São Paulo.

DE CONTI, E. ; MESSIAS, C.L. ; DE SOUZA, H.M.L. ; AZEVEDO, J.L. Electrophoretic variation in esterases and phosphatases in eleven wild-type strains of Metarhizium anisopliae. Experientia, v.36, p.293-294, 1980.

FRIGO, S.M. Variabilidade e fusão de protoplastos em Metarhizium anisopliae (Metsch.) Sorokin. Piracicaba, 1983. 119p. Tese (PhD)-Escola Superior de Agricultura "Luiz de Queiroz", Universidade de São Paulo.

FUNGARO, M.H.P. ; VIEIRA, M.L.C. ; PIZZIRANIKLEINER, A.A. ; AZEVEDO, J.L. Similaridade entre isolados de Metarhizium anisopliae baseado em análise de RAPD. Revista Brasileira de Genética, v.17, p.188, 1994 (Abstract).

GARDNER, E.J. ; SNUSTAD, D.P. Genética. Rio de Janeiro: Guanabara Koogan, 1986. cap.9, 497p.

GOLDMAN, G.H. Estudos genéticos e produção de celulase em Aspergillus niger. Piracicaba, 1988. Dissertação (mestrado) - Escola Superior de Agricultura "Luiz de Queiroz", Universidade de São Paulo. 
HAYES, W. The genetics of bacteria and their viruses. Oxford: Blackwell, 1964. 468p.

KAVA-CORDEIRO, V. ; QUEIROZ, M.V. ; AZEVEDO, J.L. Cariótipo eletroforélico de Metahizium anisopliae. Revista Brasileira de Genética, v.16, p.200, 1993 (Abstract).

LIMEIRA JR.,F.A. ; SIQUEIRA JR., J.P. ; SILVA, J.C. Survival of Metarhizium anisopliae to far UV light,8methoxypsolaren plus near UV light and nitrous acid. Revista de Microbiologia, v. 22, p. 194-195, 1991.

LUNA-ALVES-LIMA, E.A. Características citológicas e genéticas de linhagens selvagens, mutantes e diplóides de Metarhizium anisopliae (Metsch.) Sorokin. Rio de Janeiro, 1985. 260p. Tese (PhD)- Departamento de Genética, Universidade Federal do Rio de Janeiro.

MAGOON, J. ; MESSING-AL-AIDROOS, K.M. Determination of ploidy of sectors formed by mitotic recombination in the entomopathogenic fungus Metarhizium anisopliae. Transactions of the British Mycological Society, v.182, p.95-98, 1984.

MAGOON, J. ; MESSING-AL-AIDROOS, K.M. Epistatic relationships and linkage among colour markers of the imperfect entomopathogenic fungus Metarhizium anisopliae. Canadian Journal of Genetics and $\mathbf{C y}$ tology, v.28, p.96-100, 1986.

MESSIAS, C.L. Parassexualidade em Metarhizium anisopliae (Metsch.) Sorokin. Piracicaba, 1979. 73p. Tese (PhD)- Escola Superior de Agricultura "Luiz de Queiroz”, Universidade de São Paulo.

MESSIAS, C.L. ; AZEVEDO, J.L. Parasexuality in the Deuteromycete Metarhizium anisopliae. Transactions of the British Mycological Society, v.75, p.473-477, 1980.

OKINO, L.A. ; SILVA, J.C. ; SANTOS, A.L.L. ; MESSIAS, C.L. ; AZEVEDO, J.L. Determinação da sobrevivência de Metarhizium anisopliae e duas espécies de Aspergillus à radiação gama. 0 Solo, v. 70 , p.32-36, 1978

PACCOLA-MEIRELLES, L.D. ; AZEVEDO, J.L. Parasexuality in Beauveria bassiana. Journal of Invertebrate Pathology, v.57, p.172-176, 1991.
PAMPHILE, J.A. Estudos genéticos no fungo entomopatogênico Metarhizium anisopliae var. anisopliae (Metsch.) Sorokin. Piracicaba, 1992. 105p. Dissertação(mestrado)-Escola Superior de Agricultura "Luiz de Queiroz", Universidade de São Paulo.

PIMENTEL, I.C. Estudos genéticos em Paecylomices lilacinus (THOM) Samson, agente de controle biológico de nematóides. Piracicaba, 1991. 115p. Dissertação(mestrado)-Escola Superior de Agricultura "Luiz de Queiroz", Universidade de São Paulo.

PONTECORVO, G. ; ROPER, J.A. ; HEMMONS,L.M. ; MACDONALD, K.D.; BUFTON, A.J.W. The genetics of Aspergillus nidulans. Advances in Genetics , v.5, p.141-238, 1953.

RAYNER, R.W. A mycological colour chart. Kew,Surrey: Commonwealth Mycological Institute; British Mycological Society, 1970. 34p.

RIBA, G, ; AZEVEDO, J.L. ; MESSIAS, C.L. ; SILVEIRA, W.D. ; TUVESON, R. Studies of the inheritance of virulence in the entomopathogenic fungus Metarhizium anisopliae. Journal of Invertebrate Pathology, v.46, p.20-25, 1985.

ROSATO, Y.B. ; MESSIAS, C.L. ; AZEVEDO, J.L. Production of extracellular enzymes by isolates of Metarhizium anisopliae. Journal of Invertebrate Pathology, v.38, p.1-3, 1981.

SIDDIQI, O.H. Mutagenic action of nitrous acid on Aspergillus nidulans. Genetical Research, v.3, p.303314, 1962.

SILVEIRA, W.D. ; AZEVEDO, J.L. Isolation of auxotrophic mutants of Metarhizium anisopliae by the filtration enrichment technique. Revista Brasileira de Genética, v.7, p.1-8, 1984.

SILVEIRA, W.D. ; AZEVEDO, J.L. Protoplast fusion and genetic recombination in Metarhizium anisopliae. Enzyme and Microbial Technology, v.9, p.149-152, 1987.

TINLINE, R.D. ; NOVIELLO, C. Heterokaryosis in the entomogeneous fungus Metarhizium anisopliae. Mycologia, v. 63, p. 701-712, 1971.

Recebido para publicação em 20.02.95

Aceito para publicação em 25.08 .95 